\title{
Male idiopathic infertility and the TP53 polymorphism in codon 72
}

\author{
M.P. de Morais ${ }^{1}$, R.F. Curado ${ }^{1}$, K.S.F. e Silva ${ }^{1,2}$, K.K.V.O. Moura ${ }^{1}$ and \\ J.T. Arruda ${ }^{1}$ \\ ${ }^{1}$ Departamento de Biomedicina, Pontifícia Universidade Católica de Goiás, \\ Goiânia, GO, Brasil \\ ${ }^{2}$ Laboratório de Genética e Biologia Molecular, Universidade Federal de Goiás, \\ Goiânia, GO, Brasil \\ Corresponding author: K.S.F. e Silva \\ E-mail: smallbinho@hotmail.com
}

Genet. Mol. Res. 15 (4): gmr15048882

Received June 14, 2016

Accepted September 14, 2016

Published November 3, 2016

DOI http://dx.doi.org/10.4238/gmr15048882

Copyright $(\subset 2016$ The Authors. This is an open-access article distributed under the terms of the Creative Commons Attribution ShareAlike (CC BY-SA) 4.0 License.

\begin{abstract}
Many environmental agents affect the development of male germ cells at different stages. Apoptosis is common during normal spermatogenesis; it plays an important role in controlling the number of germ cells and the disposal of defective stem cells to produce functional sperm. The presence of p53 in primary spermatocytes suggests that it plays a role in the prophase of meiosis. p53 is expressed in the testis in both spermatocytes and spermatogonia. This suggests that the $\mathrm{p} 53$ gene (TP53) is important for apoptosis regulation during spermatogenesis, and may be associated with male infertility. The main causes of male infertility are genetic, physical, and pathological abnormalities, intense and prolonged exercise, aging, drug use, and long periods of sexual abstinence. Approximately $20 \%$ of male infertility is idiopathic. The Trp53 gene is involved in meiosis in male rats and mice suggesting that the p53 plays a critical role in spermatogenesis. We investigated
\end{abstract}


the association between the TP53 polymorphism in codon 72 and idiopathic male infertility in 208 semen samples: 106 showed abnormal semen analysis results and were from infertile men, and 102 were from fertile individuals (the control group). Changes in Trp53 expression are associated with the main phase regulating meiotic progression with a peak in the pachytene stage, and Trp53-deficient mice exhibit degenerative syndrome (giant cells). The genotypic and allelic frequencies were not significantly different among the groups in this study; the results suggest that the TP53 polymorphism in codon 72 is not associated with the pathogenesis of idiopathic male infertility or failure of spermatogenesis.

Key words: Idiopathic infertility; $\mathrm{p} 53$ polymorphism; Spermatogenesis

\section{INTRODUCTION}

Spermatogenesis entails continuous replication and a metamorphosis of relatively undifferentiated diploid stem cells into highly specialized haploid cells. Sperm cells have the ability to move through the female reproductive tract and fertilize an egg. This is a complex process that is controlled by the hypothalamic-pituitary axis and testicular hormones, and is susceptible to the influence of other endocrine organs such as the brain. Therefore, it is not surprising that several environmental agents can affect the development of male germ cells at different stages (Lin et al., 2010).

Apoptosis is common during normal spermatogenesis; it plays an important role in controlling the number of germ cells and the disposal of defective stem cells to produce functional sperm. Apoptotic processes during spermatogenesis are related to multiple genes and factors such as the $B c l 2$ gene family, Fas, Fas ligands, and p53 (Print and Loveland, 2000; Show et al., 2008; Lin et al., 2010). Germ cell apoptosis can also be induced by diseases or environmental disturbances such as heat stress, ionizing radiation exposure, toxic chemicals, hormonal depletion, and loss of stem cell factor signaling (Ohta et al., 2003).

Certain genes and environmental conditions associated with apoptosis in male germ cells, and the specific molecular mechanisms governing apoptosis in different conditions, have not been characterized further. The tumor suppressor protein p53 is highly expressed in the testis and is involved in apoptosis (Fouchécourt et al., 2016). The presence of p53 in a primary spermatocyte assay (Churchman et al., 2011) suggests that it plays a role in the prophase of meiosis. p53 expression in the testis occurs in spermatocytes and spermatogonia (Beumer et al., 1998). These results suggest that the p53 gene (TP53) is important in regulating apoptosis during spermatogenesis, and may be associated with male infertility.

The p53 tumor suppressor gene regulates cell growth and development. It has a chromosomal locus of $17 \mathrm{p} 13$ and encodes a $53-\mathrm{kDa}$ protein comprising 393 amino acids. It is expressed when DNA is harmed; the p53 protein binds to the damaged DNA site and disrupts cells in the G1 phase of the cell cycle (Lane, 1992), activating repair mechanisms or inducing apoptosis. When p53 mutates, damaged cells that have escaped repair or apoptosis can initiate a malignant clone (Pelúzio et al., 2006).

Codon 72 has a polymorphism that encodes the amino acids arginine (CGC; Arg72) or proline (CCC; Pro72) (Tada et al., 2001). This polymorphism takes place by a simple

Genetics and Molecular Research 15 (4): gmr15048882 
substitution of a base in the codon and results in structural alteration of the p53 protein (Lin et al., 2008). The Arg72Pro polymorphism occurs in a proline-rich domain of p53, which actively participates in the induction of apoptosis (Li et al., 2008). Dumont et al. (2003) reported that the Arg 72 allele induces apoptosis more efficiently than the Pro72 allele. The enhanced apoptotic potential of the $\operatorname{Arg} 72$ variant is due in part to a greater ability to interact with the mitochondria, where it causes the release of cytochrome c into the cytosol (Murphy, 2006).

Several studies have shown that $\operatorname{Arg} 72$ and Pro 72 variants have significant functional differences (Dumont et al., 2003; Lattuada et al., 2004) that affect the biochemical and biological properties of the 553 protein. Changing the amino acid at position 72 results in a structural change in the protein because the Pro 72 variant migrates more slowly than Arg 72 (Dumont et al., 2003).

The main causes of male infertility are associated with several factors including genetic, physical, and pathological abnormalities, intense and prolonged exercise, aging, drug use, and even long periods of sexual abstinence ( $\mathrm{Lu}$ et al., 2007). Approximately 20\% of male infertility cases are idiopathic. Increasingly, the role of genetic changes in such cases is being investigated (Olesen et al., 2001). Genetic disorders that are the main etiological cause of infertility can be attributed to chromosomal changes that can be structural, numerical, acquired, or congenital (Stankiewicz and Lupski, 2002).

Although several genetic factors have been implicated in idiopathic male infertility, many causes that involve polymorphic variants have not yet been elucidated. Thanks to the study of Matzuk and Lamb (2008), several genes that influence the testicular and sperm function of mice are now known. The Trp53 gene, which encodes the $\mathrm{p} 53$ protein in rats and mice, is involved in meiosis in males, suggesting that p53 plays a critical role in spermatogenesis (Lu et al., 2007). In the present research, we investigated the association between the TP53 polymorphism in codon 72 and idiopathic male infertility in semen samples.

\section{MATERIAL AND METHODS}

We conducted a case-control study that included semen samples from 208 men: 106 showed abnormal semen analysis results and were from infertile men, and 102 were from fertile individuals (the control group). Semen samples were collected in the Human Reproduction Laboratory (HC-UFG). Patients were classified according to alterations detected in three consecutive spermograms based on the WHO (1999) protocol. The project was approved by the Ethics Committee on research at the Catholic University of Goiás (No. 150/2004), and written informed consent was obtained from all participants.

DNA was extracted from semen samples using the $\mathrm{GFX}^{\mathrm{TM}} \mathrm{kit}$ (GE Healthcare, Milwaukee, WI, USA). The extracted samples were labeled and stored at $-20^{\circ} \mathrm{C}$. Genotyping was performed by polymerase chain reaction (PCR) following the protocol proposed by Lu et al. (2007).

We used the primers listed in Table 1 to obtain the expected amplicons for this procedure: one for the variant Pro72 and another for Arg72, both in codon 72 of the TP53 gene.

Table 1. Primer sequences and amplicon sizes.

\begin{tabular}{l|l|l|c}
\hline Variant & Sense & Anti-sense & Fragment size (bp) \\
\hline Arg & TCCCCCTTCCCGTCCCAA & CTGGTGCAGGGGCCACGC & 141 \\
\hline Pro & GCCAGAGGCTGCTCCCCC & CGTGCAAGTCACAGACTT & 177 \\
\hline
\end{tabular}

Genetics and Molecular Research 15 (4): gmr15048882 
The thermocycling conditions were specific for obtaining each amplicon (Table 2).

Table 2. Cycling protocol for the amplification of p53 fragments.

\begin{tabular}{l|c|c|c}
\hline Cycle step & Temperature & Time (min) & Number of cycles \\
\hline Initial denaturation & $94^{\circ} \mathrm{C}$ & 4 & 1 \\
\hline Denaturation & $94^{\circ} \mathrm{C}$ & 1 & 35 \\
\hline Cyclic amplification & $54^{\circ} \mathrm{C} \mathrm{Pro-}-60^{\circ} \mathrm{C} \mathrm{Arg}$ & 1 & \\
\hline Extension & $72^{\circ} \mathrm{C}$ & 1 & \\
\hline Final extension & $72^{\circ} \mathrm{C}$ & 5 & 1 \\
\hline Storage & $4{ }^{\circ} \mathrm{C}$ & $\infty$ & $\infty$ \\
\hline
\end{tabular}

To analyze the products obtained by PCR, the amplified material was subjected to $2 \%$ agarose gel electrophoresis in 1X Tris-borate ethylenediaminetetraacetic acid (EDTA) buffer (TBE). The gel was subjected to a constant electric field of $8 \mathrm{~V} / \mathrm{cm}$ for $90 \mathrm{~min}$. The gels were stained with ethidium bromide at $5 \mu \mathrm{g} / \mathrm{mL}$ for $20 \mathrm{~min}$, and documented by video. The presence of a single band of $177 \mathrm{bp}$ indicated individuals that were homozygous for $p 53$ Pro; the presence of a 144-bp band indicated homozygous $p 53 \mathrm{Arg}$ individuals. The presence of two bands, at 177 and $141 \mathrm{bp}$, characterized heterozygous (p53ProArg) individuals (Figure 1).

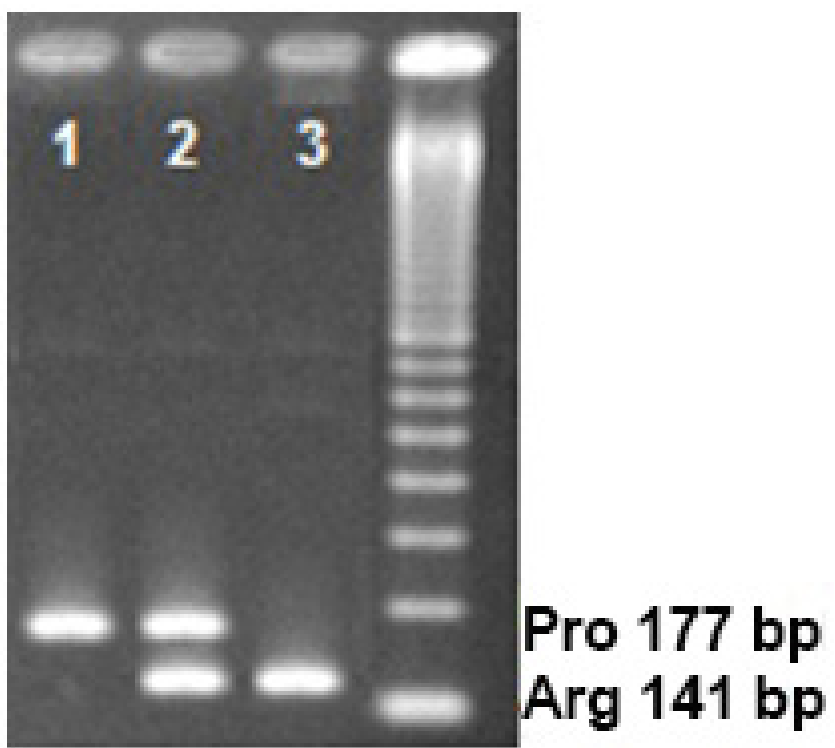

Figure 1. Agarose gel (2\%) stained with ethidium bromide showing polymerase chain reaction products of the p53 analysis. Lane 1: homozygous Pro/Pro; lane 2: heterozygous Pro/Arg; lane 3: homozygous Arg/Arg.

\section{RESULTS}

We investigated the association between the TP53 polymorphism in codon 72 and idiopathic male infertility in 208 semen samples: 106 showed abnormal semen analysis results and were from infertile men, and 102 were from fertile individuals (the control group). The average ages of the men in the case and control groups were 34.67 and 33.1 years, respectively. 
The men in the case group were 21-60 years old and the men in the control group were 20-59 years old.

We found one or more semen alteration among the patients, as described in Table 3.

Table 3. Distribution across diagnostic groups.
\begin{tabular}{l|c}
\hline Spermiogram & Number of patients \\
\hline Normal & 102 \\
\hline Teratozoospermia & 25 \\
\hline Severe oligozoospermia & 14 \\
\hline Oligozoospermia & 12 \\
\hline Asthenozoospermia/teratozoospermia & 11 \\
\hline Azoospermia & 11 \\
\hline Oligospermia/teratozoospermia & 10 \\
\hline Asthenozoospermia & 7 \\
\hline Severe oligospermia/asthenozoospermia & 6 \\
\hline Oligospermia/asthenozoospermia/teratozoospermia & 4 \\
\hline Oligospermia/asthenozoospermia & 3 \\
\hline Severe oligozoospermia/teratozoospermia & 2 \\
\hline Severe oligozoospermia/asthenozoospermia/teratozoospermia & 1 \\
\hline
\end{tabular}

In the case group we found that $23.58 \%$ (25/106) were homozygous for the Arg allele, $61.32 \%$ (65/106) were heterozygous for the Arg-Pro alleles, and 15.09\% (16/106) were homozygous for the Pro allele. In the control group we found that $19.60 \%$ (20/102) were homozygous for the Arg allele, 55.88\% (57/102) were heterozygous for the Arg-Pro alleles, and $24.50 \%$ (25/102) were homozygous for the Pro allele (Table 4). The results were not significant according to the statistical analysis.

Table 4. Distribution of the genotypic and allelic frequencies.

\begin{tabular}{|c|c|c|c|}
\hline & Altered [N (\%)] & Normal [N (\%)] & \\
\hline \multicolumn{4}{|l|}{ Genotype } \\
\hline Arg/Arg & $25(23.58 \%)$ & $20(19.60 \%)$ & \multirow[t]{3}{*}{$\mathrm{P}=0.2254$} \\
\hline Arg/Pro & $65(61.32 \%)$ & $57(55.88 \%)$ & \\
\hline Pro/Pro & $16(15.09 \%)$ & $25(24.50 \%)$ & \\
\hline Total & 106 & 102 & \\
\hline \multicolumn{4}{|l|}{ Allele } \\
\hline Arg & $115(0.55)$ & $97(0.46)$ & \multirow[t]{2}{*}{$\mathrm{P}=0.2049$} \\
\hline Pro & $97(0.46)$ & $107(0.51)$ & \\
\hline Total & 212 & 204 & \\
\hline
\end{tabular}

$\mathrm{N}=$ sample size; $\mathrm{P}=$ chi-square value.

\section{DISCUSSION}

The polymorphism of codon 72 of TP53 has been studied extensively because of its impact on the coding sequence of the gene, which is related to the suppression of cell growth and plays an important role in apoptosis (Dumont et al., 2003; Lattuada et al., 2004; Siddique and Sabapathy, 2006). However, there is little scientific literature about the association between this polymorphism and idiopathic male infertility; Lu et al. (2007) reported that this association was not statistically significant in a Chinese population.

The large number of cell divisions that take place during spermatogenesis, and 
consequently the high rate of DNA replication, increases the chance of mutation in the germ cells (Jobling and Tyler-Smith, 2003). Maintaining the integrity of testicular germ cells during spermatogenesis is crucial to fertility. Spontaneous germ cell death has been recognized as a normal cellular process in the mammalian testis (Kerr, 1992). Cell suppression has been found at different stages of development including in spermatogonia (Huckins, 1978; Allan et al., 1992), spermatocytes, and spermatids (Kerr, 1992).

Although p53 plays a role in normal physiological conditions in the germ cells, it has also been found in cells damaged by external agents. Male germ cells are sensitive to heat (Chowdhury and Steinberger, 1964) and apoptosis occurs in germ cells subjected to elevated temperatures (Shikone et al., 1994).

In this study we found no statistically significant differences among the populations, both in terms of genotype frequency $(\mathrm{P}=0.2254)$ and allelic frequency $(\mathrm{P}=0.2049)$. There was a higher prevalence of the p53Arg allele in the case group, but the prevalence of the p53Pro allele was higher in the control group (Table 4). The distribution of sperm was not significantly different between the polymorphic variants, indicating that the importance of each clinical characteristic does not depend on the genotype present in the analyzed patient.

The controversy surrounding the data on p53 in the literature can be attributed to ethnic differences among the populations studied. Moreover, other factors such as the sample size, the type of sample used as a source of DNA, the detection technique used, and variations in the laboratory protocol may have contributed to the discrepancy in the results (Brenna et al., 2004).

Oscillation or genetic drift, acting together with natural selection, involves random fluctuations in the frequency of alleles; owing to sampling errors, there is a tendency to set one or the other allele, especially in very small populations (Rotter et al., 1993). Thus, genetic drift may also be associated with the discrepancy in the results found in the literature, because the stability of the allelic frequencies varies greatly according to the size of the population.

Both TP53 isoforms are able to stimulate repair and apoptosis, but with different efficiencies. For this reason, the polymorphism in codon 72 may serve as a genetic modifier, allowing the balance of the biological processes as a result of ecological and/or evolutionary adaptation (Siddique and Sabapathy, 2006). Each polymorphic variant may have been selected by evolution for a given specific function. One can hypothesize that when subjected to certain cellular stress signals, an individual carrier of the p53Arg variant might respond by preferentially triggering apoptosis, whereas a carrier of the p53Pro allele might trigger the repair of the affected cell.

Apoptosis can be the first line of defense of the body to genotoxic stress in carriers of the p53Arg allele. This fact is supported by clinical data showing that patients with this variant without mutations of the TP53 gene respond more satisfactorily to chemotherapy and survive longer compared with carriers of the p53Pro allele (Siddique and Sabapathy, 2006). However, p53Pro induces blockade of the cell cycle in G1 and p53-dependent activation of repair mechanisms more effectively than p53Arg (Dumont et al., 2003; Bojesen and Nordestgaard, 2008).

Schwartz et al. (1993) postulated that a lack of p53 significantly affects the overall yield of sperm motility, indicating that a lack of TP53 reduces the "functional" yield of spermatozoa because they observed a higher percentage of abnormal spermatozoa and reduced fertility.

A role for $\mathrm{p} 53$ in spermatogenesis was suggested by the observation that changes in TP53 expression are associated with the main phase regulating meiotic progression with a peak in the pachytene stage (Schwartz et al., 1993), and Trp53-deficient mice exhibit degenerative syndrome manifested by the occurrence of giant cells (Rotter et al., 1993).

Genetics and Molecular Research 15 (4): gmr15048882 
In the current study the genotypic and allelic frequencies were not significantly different among the groups, suggesting that the TP53 gene polymorphism in codon 72 is not associated with the pathogenesis of idiopathic male infertility or failure of spermatogenesis.

\title{
Conflicts of interest
}

The authors declare no conflict of interest.

\section{ACKNOWLEDGMENTS}

\author{
Research supported by funding provided by PUC-GO University.
}

\section{REFERENCES}

Allan DJ, Harmon BV and Roberts SA (1992). Spermatogonial apoptosis has three morphologically recognizable phases and shows no circadian rhythm during normal spermatogenesis in the rat. Cell Prolif. 25: 241-250. http://dx.doi. org/10.1111/j.1365-2184.1992.tb01399.x

Beumer TL, Roepers-Gajadien HL, Gademan IS, van Buul PP, et al. (1998). The role of the tumor suppressor p53 in spermatogenesis. Cell Death Differ. 5: 669-677. http://dx.doi.org/10.1038/sj.cdd.4400396

Bojesen SE and Nordestgaard BG (2008). The common germline Arg72Pro polymorphism of p53 and increased longevity in humans. Cell Cycle 7: 158-163. http://dx.doi.org/10.4161/cc.7.2.5249

Brenna SMF, Silva IDCG, Zeferino LC, Pereira J, et al. (2004). Prevalence of codon 72 p53 polymorphism in Brazilian women with cervix cancer. Genet. Mol. Biol. 27: 496-499. http://dx.doi.org/10.1590/S1415-47572004000400005

Chowdhury AK and Steinberger E (1964). A quantitative study of the effect of heat on germinal epithelium of rat testes. Am. J. Anat. 115: 509-524. http://dx.doi.org/10.1002/aja.1001150307

Churchman ML, Roig I, Jasin M, Keeney S, et al. (2011). Expression of arf tumor suppressor in spermatogonia facilitates meiotic progression in male germ cells. PLoS Genet. 7: e1002157. http://dx.doi.org/10.1371/journal.pgen.1002157

Dumont P, Leu JI, Della Pietra AC, 3rd, George DL, et al. (2003). The codon 72 polymorphic variants of p53 have markedly different apoptotic potential. Nat. Genet. 33: 357-365. http://dx.doi.org/10.1038/ng1093

Fouchécourt S, Livera G, Messiaen S, Fumel B, et al. (2016). Apoptosis of Sertoli cells after conditional ablation of murine double minute $2(\mathrm{Mdm} 2)$ gene is p53-dependent and results in male sterility. Cell Death Differ. 23: 521-530. http:// dx.doi.org/10.1038/cdd.2015.120

Huckins C (1978). The morphology and kinetics of spermatogonial degeneration in normal adult rats: an analysis using a simplified classification of the germinal epithelium. Anat. Rec. 190: 905-926. http://dx.doi.org/10.1002/ ar.1091900410

Jobling MA and Tyler-Smith C (2003). The human Y chromosome: an evolutionary marker comes of age. Nat. Rev. Genet. 4: 598-612. http://dx.doi.org/10.1038/nrg1124

Kerr JB (1992). Spontaneous degeneration of germ cells in normal rat testis: assessment of cell types and frequency during the spermatogenic cycle. J. Reprod. Fertil. 95: 825-830. http://dx.doi.org/10.1530/jrf.0.0950825

Lane DP (1992). Cancer. p53, guardian of the genome. Nature 358: 15-16. http://dx.doi.org/10.1038/358015a0

Lattuada D, Viganò P, Somigliana E, Abbiati A, et al. (2004). Analysis of the codon 72 polymorphism of the TP53 gene in patients with endometriosis. Mol. Hum. Reprod. 10: 651-654. http://dx.doi.org/10.1093/molehr/gah093

Li C, Chen K, Liu Z, Wang LE, et al. (2008). Polymorphisms of TP53 Arg72Pro, but not p73 G4C14>A4TA4 and p21 Ser31 Arg, contribute to risk of cutaneous melanoma. J. Invest. Dermatol. 128: 1585-1588. http://dx.doi.org/10.1038/ sj.jid. 5701186

Lin HY, Huang CH, Wu WJ, Chang LC, et al. (2008). TP53 codon 72 Gene Polymorphism Paradox in Associated with Various Carcinoma Incidences, Invasiveness and Chemotherapy Responses. Int. J. Biomed. Sci. 4: 248-254.

Lin YC, Yao PL and Richburg JH (2010). FasL gene-deficient mice display a limited disruption in spermatogenesis and inhibition of mono-(2-ethylhexyl) phthalate-induced germ cell apoptosis. Toxicol. Sci. 114: 335-345. http://dx.doi. org/10.1093/toxsci/kfq015

Lu NX, Xia YK, Gu AH, Liang J, et al. (2007). Lack of association between polymorphisms in p53 gene and spermatogenetic failure in a Chinese population. Andrologia 39: 223-228. http://dx.doi.org/10.1111/j.1439-0272.2007.00790.x

Genetics and Molecular Research 15 (4): gmr15048882 
Matzuk MM and Lamb DJ (2008). The biology of infertility: research advances and clinical challenges. Nat. Med. 14: 1197-1213. http://dx.doi.org/10.1038/nm.f.1895

Murphy ME (2006). Polymorphic variants in the p53 pathway. Cell Death Differ. 13: 916-920. http://dx.doi.org/10.1038/ sj.cdd. 4401907

Ohta H, Aizawa S and Nishimune Y (2003). Functional analysis of the p53 gene in apoptosis induced by heat stress or loss of stem cell factor signaling in mouse male germ cells. Biol. Reprod. 68: 2249-2254. http://dx.doi.org/10.1095/ biolreprod.102.014779

Olesen C, Hansen C, Bendsen E, Byskov AG, et al. (2001). Identification of human candidate genes for male infertility by digital differential display. Mol. Hum. Reprod. 7: 11-20. http://dx.doi.org/10.1093/molehr/7.1.11

Pelúzio MCG, Volp ACP, Queiroz IC, Brito CJ, et al. (2006). As proteínas supressoras em neoplasias malignas Conhecendo seu papel. Rev. Bras. Nutr. Clín. 21: 233-238.

Print CG and Loveland KL (2000). Germ cell suicide: new insights into apoptosis during spermatogenesis. BioEssays 22: 423-430. http://dx.doi.org/10.1002/(SICI)1521-1878(200005)22:5<423::AID-BIES4>3.0.CO;2-0

Rotter V, Schwartz D, Almon E, Goldfinger N, et al. (1993). Mice with reduced levels of p53 protein exhibit the testicular giant-cell degenerative syndrome. Proc. Natl. Acad. Sci. USA 90: 9075-9079. http://dx.doi.org/10.1073/ pnas. 90.19 .9075

Schwartz D, Goldfinger N and Rotter V (1993). Expression of p53 protein in spermatogenesis is confined to the tetraploid pachytene primary spermatocytes. Oncogene 8: 1487-1494.

Shikone T, Billig H and Hsueh AJ (1994). Experimentally induced cryptorchidism increases apoptosis in rat testis. Biol. Reprod. 51: 865-872. http://dx.doi.org/10.1095/biolreprod51.5.865

Show MD, Hill CM, Anway MD, Wright WW, et al. (2008). Phosphorylation of mitogen-activated protein kinase 8 (MAPK8) is associated with germ cell apoptosis and redistribution of the Bcl2-modifying factor (BMF). J. Androl. 29: 338-344. http://dx.doi.org/10.2164/jandrol.107.003558

Siddique M and Sabapathy K (2006). Trp53-dependent DNA-repair is affected by the codon 72 polymorphism. Oncogene 25: 3489-3500. http://dx.doi.org/10.1038/sj.onc.1209405

Stankiewicz P and Lupski JR (2002). Genome architecture, rearrangements and genomic disorders. Trends Genet. 18: 7482. http://dx.doi.org/10.1016/S0168-9525(02)02592-1

Tada M, Furuuchi K, Kaneda M, Matsumoto J, et al. (2001). Inactivate the remaining p53 allele or the alternate p73? Preferential selection of the Arg72 polymorphism in cancers with recessive p53 mutants but not transdominant mutants. Carcinogenesis 22: 515-517. http://dx.doi.org/10.1093/carcin/22.3.515

WHO (1999). World Health Organization Laboratory manual for the examination of human semen and sperm-cervical mucus interaction. 4th edn. Cambridge University Press, Cambridge.

Genetics and Molecular Research 15 (4): gmr15048882 